\title{
ASIAN GAMES 2018 AS A SPORT TOURISM ELEMENT IN THE ITINERARY OF INBOUND TOUR
}

\author{
$1^{\text {st }}$ Khoirul Fajri \\ STIEPAR YAPARI \\ Bandung, Indonesia \\ khoirul.fajri@yahoo.com
}

\author{
$2^{\text {nd }}$ Nova Riana \\ STIEPAR YAPARI \\ Bandung, Indonesia \\ nova.riana@ymail.com
}

\author{
$3^{\text {rd }}$ Titing Kartika \\ STIEPAR YAPARI \\ Bandung, Indonesia \\ nengtiting_kartika@yahoo.co.id
}

\begin{abstract}
The appointment of Indonesia as the event organizer of Asian Games 2018 could be seen as a challenge and at the same time is an opportunity to show the world that Indonesia is capable in hosting this such big event. This international sport event like Asian Games could be classified as world sport tourism, especially in Asia. Various kind of sports that matched or competed during the period of Asian Games could be offered as a tourism attraction.

From the perspective of Tourism Actors, this event is also an opportunity to add an alternative product in tour packages, especially in Sport Tourism for inbound tourists. This opportunity is welcomed and highly responded by tour operators in Bandung by creating some variant of tour packages for inbound tourists, consisted of visiting places with Indonesia culture, guiding to watch the matches in Asian Games, visiting local tourism destinations, local gastronomy, and center of local tokens. These various activities bonded in an inbound tour package thus will increase the product innovation on tour package. Not only provide revenue for the travel company, but also revenue for the two cities that chosen as venues for Asian Games event, Jakarta and Palembang.

This research aims to analyze the packaging of Asian Games as tourism attraction for inbound tour packages, using Itinerary and Design Analysis Method with qualitative approach. Itinerary and Design Analysis applied on some tour and travel companies in Bandung, West Java, especially companies in ASITA. Whilst data collection was conducted by interview techniques, literature studies, and questionnaire technique.
\end{abstract}

This research conducted by the using of qualitative approach, that analyze how is the attractiveness of a tour package that consisted of an Asian Games match in it's itinerary, in order to grab the tourists' desires. In analyzing on the tourism package, the authors break it down base on package compositions and the variety in packaging; those are theme, itinerary, and price.

In an effort to sharpen the corridor of the study, researchers formulate the problems as follows: (1) How is the analysis on the contribution of Asian Games event as a tourism attraction? (2) How is the formulation of packaging the Asian Games as sport tourism attractions in inbound tour packages?

The outcome of this research found that the Asian Games event has a good contribution as a sport tourism attraction, in arranging a tour package. This research also found that the tour and travel companies applied a formula of "mix n match" itinerary that combines sport tourism with available national attractions spots.
Keywords-Asian Games, Tour Packaging, Tour and Travel Company, inbound

\section{INTRODUCTION}

The development of the tourism industry as a business venture, almost all of its activities are driven by private parties who play a role in it, including the travel agency. From these developments shows that the Travel Bureau is one of the parties that play a role in the development of the tourism industry in addition to accommodation service companies, transportation, management of tourist attractions, and others. The main role of the Travel Bureau according to Desky (2001: 3) is as a liaison between tourists and companies providing travel facilities needed by tourists to reach the destination. Meanwhile, according to UNWTO, which is one of the most important tourism organizations in the world, it provides data that around $70 \%$ of the flow of tourism in the world is handled and managed by a travel agency.

In addition, according to RI Legislation No. 10 of 2009 concerning tourism that Travel Agencies / tour operators have an important role in advancing tourism development, because apart from its main function of making tour packages, Travel Agencies can also be intermediaries in selling products of other companies such as transportation companies, hospitality and attractions tourist attractions. From these two sources explained the main function of the Travel Bureau is to make a product that is packaged for tourists, namely tour package, in addition to the function as an intermediary between prospective customers (tourists) with other companies.

Nuriata (2014:27) said that in accordance with the nature of a product both services and goods viewed from the aspect of preparation that the product must be made based on two orientations, namely the product or aspect of product interests and orientation in terms of consumer interests. So that in the activity of arranging a tourism event or tour itinerary, it is necessary to have a diversity of destinations, both tourist attraction or performances (events) both regular and non-regular that will be visited. As one of the efforts to make inbound tour package products, namely to bring in foreign tourists through variations in determining destinations that will be included in the itinerary, including 
through the introduction and development of activities or international class sports events such as sports activities. at the Asian Games.

Based on the above phenomenon, this study analyzes how to use the 2018 Asian Games event as an itinerary sport tourism in an inbound tour package. The objectives of the research are (1) to analyze Asian Games events as tourist attractions and (2) to find out the Asian Games packaging formulation as a sport tourism attraction in inbound tour packages?

\section{LITERATURE REVIEW}

\section{A. Asian Games and Event}

The Asian Games are international sports events involving countries in Asia. In 2018, the Asian Games are held in Indonesia with centers in Jakarta and Palembang. The Asian Games according to the OCA (Organization Council of Asian) are competitions of various sports participated by Asian athletes, held every 4 (four) years in the Asian region. In the context of event management, the Asia Games can be categorized as special event as shown in figure 1 .

There are several understandings of this event, among them are contained in the Big Indonesian Dictionary (KBBI) which explains the event is the thing or subject that will be discussed (in meetings, negotiations, etc.). The event is also defined as an activity that is held to commemorate important matters as long as humans are individually or in groups that are bound by custom, culture, tradition and religion which are held for specific purposes and involve the community environment held at a certain time (Noor, 2013) .Moreover, Shone and Parry (2002) states that special events are that phenomenon arising from non-routine occasion which have leisure, cultural, personal or organizational objectives set apart from normal activity of daily life, whose purpose $\mathrm{s}$ to enlighten, celebrate, entertain or challenge the experience of a group of people. Another definition is described by Getz (1997) that event is those non-routine occasions set apart from the normal activity of daily life of a group of people.

Figure 1. Special Events Catgeory

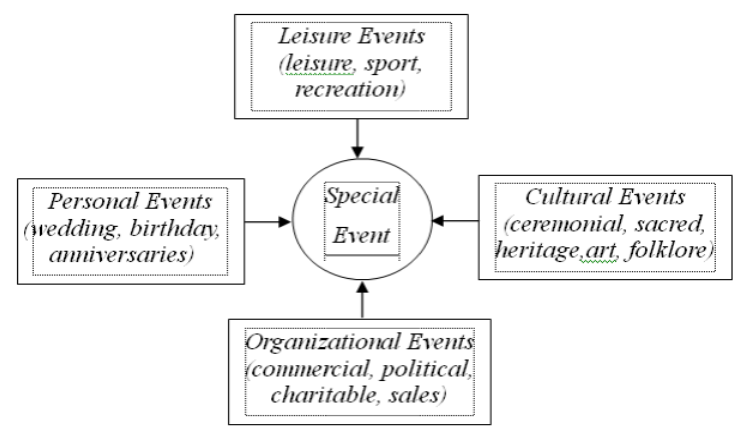

Source: Shone dan Parry (2002)

\section{B. Tourism and Tour Packages}

According to the WATA (World Association of Travel Agent) provisions, tourism is a trip for more than three days, organized by a travel office in the city and the event includes browsing in various places or cities both inside and outside the country.

Meanwhile, according to Government Legislation number 10, year 2009 concerning tourism: tourism is a journey carried out by a person or group of people by visiting a particular place for recreational purposes, personal development, or studying the tourist attractions that he visits in a temporary period.

Another opinion is from Hornby AS in Suyitno (2001: 8), tour is journey in which a short stays are made at a number of places, and the traveler finally returns to his or her own place. (Travel is a journey where someone is in the trip temporarily stopped in several places and finally returned to the original place where he began to travel.)

Referring to the above definitions, it can be concluded that the notion of tourism emphasizes more on activities carried out by tourists in a tourism journey. In a tourist trip, tourists visit a historical tourist spot so that tourists can be said to have carried out historical tourism activities. In the sense that activity is done is to enjoy historical objects. This is an illustration of activities in a tourism trip. Where activities in tourism are very much determined by the interest of tourists themselves. Not only determined by tourists' interests but based on available tourism resources. Therefore there are many historical tourism terms, cultural wista, natural tourism, educational tourism, sports tourism and other types of tourism.

While the types of tourism in terms of activities or activities according to Kesrul, (39-40: 2003) consist of; Pleasure Tourism, Recreation tourism, cultur tourism, adventure tourism, business tourism and Sport tourism, or sports, namely tourism activities with scheduled events as the main visit to visit regional or international sports events.

In tourist activities, dining tour packages become a very important part. Tour Packages according to Nuriata (2014: 11) are defined as a tourist trip with one or more visit destinations arranged from certain travel facilities in a fixed travel event, and sold as a single price that concerns all components of the tour.

Damardjati in Suyitno (2001: 67) defines a package tour as a tour plan or event that has been arranged in a fixed manner, with a certain price that includes costs for transfer/transportation, accommodation/hotel facilities, and sightseeing in the city, these attractions will be cheaper to fall compared to specially planned tours or request.

Whereas according to Desky (2001: 23) The tour package is a combination of several tourism products, a minimum of two products, which are packaged into a single price that cannot be separated from each other.

Based on the above experts' definitions about tour packages, the authors conclude that tour package is a travel 
product that is planned and organized by a travel agency where the travel program has one or several visit destinations that involve certain travel facilities that have a single price concerning all components of a tour.

The types of tour packages include:

1). According to Suyitno (2001: 69) in terms of its arrangement, package tours can be divided into two, namely Ready Made Tour and Tailor Made Tour.

a. Ready Made Tour

Is a tour package prepared by the tour operator without waiting for requests from prospective participants. In other words, the preparation of the product is entirely on the initiative of the tour operator.

b. Tailor Made Tour

A tour package that has been prepared after a request from prospective participants.

2) Definition of tour packages in terms of the origin of tourists. According to the Desky (2001: 23), Inbound is a tour package designed for the consumption of foreign tourists with the aim of traveling domestically. While Outbound is a tour package designed for consumption of domestic tourists, with the of traveling abroad. In addition Yoeti (2010: 75) inbound tourism is tourism that specifically attracts or brings in foreign tourists (foreign tourists) into the country in order to increase foreign exchange earnings from the tourism sector. This type of tourism will succeed, if domestic tourism can be developed properly.

\section{C.Itinerary}

Itinerary according to Suyitno (2001) in a travel planning book gives an understanding "A document that can be used to illustrate the implementation of a tour or become a shadow product that will be accepted by consumers". Meanwhile, according to Robert T Reilly is still in Suyitno, giving a definition; "A day byday schedule of travel plans and arrangements on a specific tour" According to M. Kesrul (2003: 41), the itinerary or tour program is: "A document that contains a travel program, from the departure to the destination to return to the place of origin with an explanation of the travel time, the object of the visit and the place to eat.

\section{METHODOLOGY}

The methodology used was qualitative approach. The itinerary and design analysis of travel companies in Bandung, West Java, especially companies in ASITA. Whilst data collection was conducted by interview techniques, literature studies, and questionnaire technique.

The subject of the study was 25 (twenty-five) travel tour companies that were active in inbound tourism package sales activities from 187 member travel company companies in Bandung Raya and became members of the ASITA West Java DPD. Sorted from 187 companies there are 25 companies as sample that are active in selling inbound tour packages for destination cities including: Jakarta, Bogor, Bandung, Yogyakarta, Bali, Palembang.

\section{RESULT AND DISCUSSION}

Based on the results of the research that has been done, the following findings are obtained:

\section{A. How to analyze the Asian Games event as a tourist attraction.}

With the increasing number of Travel Agencies in West Java generally and Bandung especially in the last two decades from year to year, it was recorded in 2015 that travel companies who were members of the ASITA West Java DPD 295 travel companies and up to July 2018388 companies were recorded and this number excluding travel companies that have not joined the ASITA West Java DPD travel company association (www.asitajabar.org). The growth of this travel business has led to an increasingly diverse Itinerary tour or event from tour packages made by each travel agency and offered to tourists which all vary according to the needs and tastes of tourists.

The 388 of travel agency companies in West Java are being members of the ASITA West Java Chapter. A number of 187 among those 388 companies are operated in Bandung Raya. Based on the data below, there are 25 companies that still actively selling tour packages for the market or foreign tourists, known as inbound

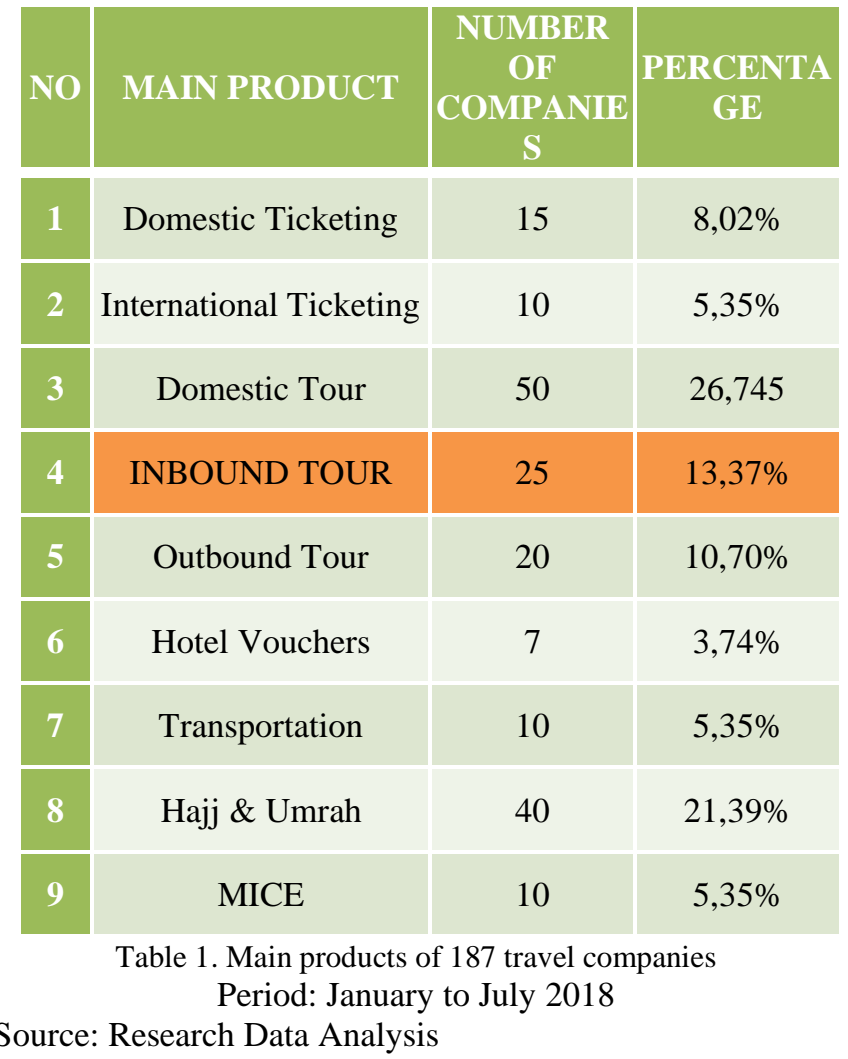


Table 2. List of 25 travel agencies (as sample of bandung raya area) With inbound tour main product, Members of asita, west java chapter period: jan 2016 to jul 2018

\begin{tabular}{|c|c|c|c|}
\hline NO & $\begin{array}{l}\text { NAME OF } \\
\text { COMPANY }\end{array}$ & ADDRESS & PHONE \\
\hline 1 & AEROTRAVEL & $\begin{array}{c}\text { Jalan Gurame No. } 12 \\
\text { Bandung }\end{array}$ & $\begin{array}{c}022- \\
87342215- \\
17\end{array}$ \\
\hline 2 & $\begin{array}{l}\text { ALL BANDUNG } \\
\text { TRAVEL PT }\end{array}$ & $\begin{array}{c}\text { Ruko BTD Jl. Banyak } \\
\text { Niaga Kulon No. } 21 \\
\text { Kota Baru } \\
\text { Parahyangan }\end{array}$ & $\begin{array}{c}022- \\
8793660\end{array}$ \\
\hline 3 & $\begin{array}{l}\text { ALTANA } \\
\text { KENCANA } \\
\text { NUSANTARA }\end{array}$ & $\begin{array}{l}\text { J1. LL. RE. } \\
\text { Martadinata No. } 4 \\
\text { Bandung }\end{array}$ & $\begin{array}{c}0853872892 \\
97\end{array}$ \\
\hline 4 & $\begin{array}{l}\text { AMASARI TOURS } \\
\text { (D/H SARI ) }\end{array}$ & $\begin{array}{l}\text { Jl. Tamansari No.72, } \\
\text { Jawa Barat } 40132\end{array}$ & $\begin{array}{c}022- \\
2504123 \\
2758722\end{array}$ \\
\hline 5 & $\begin{array}{l}\text { ATHASE TOURS } \\
\& \text { TRAVEL PT }\end{array}$ & $\begin{array}{l}\text { J1. Asmarandana No. } \\
30 \text { Bandung }\end{array}$ & $\begin{array}{c}022- \\
76164225\end{array}$ \\
\hline 6 & $\begin{array}{l}\text { BANDAR } \\
\text { ANUGRAH } \\
\text { MANDIRI }\end{array}$ & $\begin{array}{l}\text { Taman Kopo Indah } \\
\text { III Ruko C-112 bdg }\end{array}$ & $\begin{array}{c}022- \\
61014005\end{array}$ \\
\hline 7 & $\begin{array}{l}\text { EXOTIC JAVA } \\
\text { TRAILS }\end{array}$ & $\begin{array}{l}\text { J1. Merkuri Tengah } \\
\text { No. 18, Margahayu }\end{array}$ & $\begin{array}{c}022- \\
87804319\end{array}$ \\
\hline 8 & $\begin{array}{l}\text { BARAYA } \\
\text { KHARISMA JAYA } \\
\text { PT }\end{array}$ & $\begin{array}{l}\text { Jl. Cikutra Baru VI } \\
\text { No. } 26 \text { Bandung }\end{array}$ & $\begin{array}{c}022- \\
87831799\end{array}$ \\
\hline 9 & $\begin{array}{l}\text { BATIK } \\
\text { HOLIDAYS }\end{array}$ & $\begin{array}{l}\text { J1. Guntur No. } 17 \\
\text { Bandung } 40262\end{array}$ & $\begin{array}{c}022- \\
7322984\end{array}$ \\
\hline 10 & BHARATOURS PT & $\begin{array}{l}\text { Jl. Saninten No. } 53 \\
\text { Bandung }\end{array}$ & $\begin{array}{l}022-723 \\
4150 / 51\end{array}$ \\
\hline 11 & $\begin{array}{l}\text { BIRAMA } \\
\text { IDAMAN } \\
\text { EXPRESS PT }\end{array}$ & $\begin{array}{c}\text { Jl. Dipati Ukur No. } 23 \\
\text { Bdg }\end{array}$ & $\begin{array}{c}022-250 \\
4871\end{array}$ \\
\hline 12 & $\begin{array}{l}\text { EXCELLENT } \\
\text { HOLIDAYS PT }\end{array}$ & $\begin{array}{l}\text { JL. WR. Supratman } \\
\text { No.3 Bandung }\end{array}$ & $\begin{array}{c}022-7200 \\
199 / 299\end{array}$ \\
\hline 13 & $\begin{array}{l}\text { EXODUS TOUR } \\
\text { PT }\end{array}$ & $\begin{array}{l}\text { Jl. Pasirkaliki No. } 186 \\
\text { C Bandung }\end{array}$ & $\begin{array}{c}022-426 \\
4899-421 \\
6707\end{array}$ \\
\hline 14 & $\begin{array}{l}\text { FRES INDONESIA } \\
\text { WISATA }\end{array}$ & $\begin{array}{c}\text { Jalan Anggrek No. } 55 \\
\text { - Bandung }\end{array}$ & $\begin{array}{c}022- \\
7234721\end{array}$ \\
\hline 15 & $\begin{array}{l}\text { GLOBAL } \\
\text { MENTARI PT }\end{array}$ & $\begin{array}{l}\text { Jl. Raden Patah No. } \\
39 \text { Bandung }\end{array}$ & $\begin{array}{l}022-250 \\
2529 \\
91142778\end{array}$ \\
\hline 16 & $\begin{array}{l}\text { GRAND } \\
\text { TRAVELLING } \\
\text { INDONESIA }\end{array}$ & $\begin{array}{c}\text { Jl. Moch. Iskat No. } 20 \\
\text { Bandung }\end{array}$ & $\begin{array}{c}022- \\
6062679\end{array}$ \\
\hline 17 & $\begin{array}{l}\text { JACKAL } \\
\text { HOLIDAYS PT }\end{array}$ & $\begin{array}{l}\text { Jl. Soekarno - Hatta } \\
\text { No. } 593 \text { Bandung }\end{array}$ & $\begin{array}{l}022-731 \\
9888 \\
7319588\end{array}$ \\
\hline 18 & $\begin{array}{l}\text { JODIREXA } \\
\text { BHUVANA } \\
\text { PRIMA TOURS \& }\end{array}$ & $\begin{array}{l}\text { Antapani Residence } \\
\text { C-9 Jl. Malangbong } \\
\text { Raya Antapani - Bdg }\end{array}$ & $\begin{array}{c}022- \\
70765758, \\
87240202\end{array}$ \\
\hline
\end{tabular}

\begin{tabular}{|c|c|c|c|}
\hline NO & $\begin{array}{l}\text { NAME OF } \\
\text { COMPANY }\end{array}$ & ADDRESS & PHONE \\
\hline \multicolumn{4}{|c|}{ TRAVEL } \\
\hline 19 & MY DUTATOUR & $\begin{array}{l}\text { J1. Belitung No. 3D } \\
\text { Bandung }\end{array}$ & $\begin{array}{c}022- \\
4215758 \\
\text { (hunting) }\end{array}$ \\
\hline 20 & РACTO PT & $\begin{array}{l}\text { Savoy Homann Hotel; } \\
\text { J1. Asia Afrika No. } \\
112 \text { Bandung } 40261\end{array}$ & $\begin{array}{c}022- \\
85880488\end{array}$ \\
\hline 21 & $\begin{array}{l}\text { SUNDA } \\
\text { NETWORK }\end{array}$ & $\begin{array}{l}\text { Jl. Guntur Sari Wetan } \\
\text { No. } 29 \text { Bandung }\end{array}$ & $\begin{array}{c}022- \\
70053372 \\
7308507\end{array}$ \\
\hline 22 & $\begin{array}{l}\text { TAMA PUTRA } \\
\text { WISATA PT }\end{array}$ & $\begin{array}{c}\text { Jl. Abdulrahman } \\
\text { Saleh No.9, } \\
\text { Komp.City Square C } \\
1 \text { Bdg. }\end{array}$ & $\begin{array}{c}022-612 \\
5390-1-2\end{array}$ \\
\hline 23 & $\begin{array}{l}\text { TAMBATAN } \\
\text { HATI PT }\end{array}$ & $\begin{array}{l}\text { Jl. Belitung No. } 3 \\
\text { Ruko A - Bandung }\end{array}$ & $\begin{array}{c}022- \\
4207940\end{array}$ \\
\hline 24 & $\begin{array}{l}\text { TRAVALINK } \\
\text { INDONESIA }\end{array}$ & $\begin{array}{c}\text { Jl. Batik Uwit No. } 9 \\
\text { Bandung }\end{array}$ & $\begin{array}{c}022- \\
2501786\end{array}$ \\
\hline 25 & $\begin{array}{l}\text { UNIVERSAL } \\
\text { HOLIDAY } \\
\text { TRAVEL }\end{array}$ & $\begin{array}{l}\text { Jl. Anggrek No. } 11 \\
\text { Bandung }\end{array}$ & $\begin{array}{c}022-723 \\
0999\end{array}$ \\
\hline
\end{tabular}

Source: Research Data Analysis

Based on the data gathered by questionnaire, sorted from 187 companies a number of 25 travel companies which all are members of ASITA (Association on Indonesian Travel Agencies), that selling tour package for foreign tourists.

Table 3. Rank of 10 best provinces/cities as main destinations in itinerary January 2016 to january 2016

\begin{tabular}{|c|c|c|c|}
\hline NO & $\begin{array}{l}\text { PROVINCE/ } \\
\text { CITY }\end{array}$ & $\begin{array}{c}\text { AVERAGE OF } \\
\text { PACKAGE'S } \\
\text { DURATION }\end{array}$ & $\begin{array}{l}\text { QUANTITY } \\
\text { OF TRA VEL } \\
\text { AGENCIES }\end{array}$ \\
\hline 1 & Bali & 4 days 3 nights & 25 \\
\hline 2 & Bandung & 3 days 2 nights & 24 \\
\hline 3 & Jakarta & 2 days 1 night & 20 \\
\hline 4 & Yogyakarta & 3 days 2 nights & 19 \\
\hline 5 & Medan & 4 days 3 nights & 15 \\
\hline 6 & Makassar & 4 days 3 nights & 15 \\
\hline 7 & Padang & 3 days 2 nights & 13 \\
\hline 8 & Lampung & 2 days 1 night & 10 \\
\hline 9 & Aceh & 3 days 2 nights & 6 \\
\hline 10 & Palembang & 3 days 2 nights & 5 \\
\hline
\end{tabular}

Source: Research Data Analysis 
Table 3 showed the rank of foreign tourists' request on inbound tour package on 25 travel companies. The table also showed the provinces or cities chosen as tour destinations in the itinerary.Bali, Bandung and Jakarta are the three top in the rank. The travel operator still need some more activities to increase the attractions of tour packages for foreign tourists on the other cities/provinces, out of the three top ones. At least, there should be some variety in tour package offering, such as innovation in the arrangement of itinerary.

Table 4. Sales of inbound tour package by 25 sample of travel agencies

January 2016 to Desember 2016

\begin{tabular}{|c|c|c|c|c|c|}
\hline RANK & $\begin{array}{l}\text { PROVINCE } \\
\text { / CITY }\end{array}$ & $\begin{array}{l}\text { A VERAGE OF } \\
\text { PACKAGE'S } \\
\text { DURATION }\end{array}$ & $\begin{array}{c}\text { QTY OF } \\
\text { TRAVEL } \\
\text { AGENCIES }\end{array}$ & $\begin{array}{l}\text { AVERAGE } \\
\text { SALES }\end{array}$ & $\begin{array}{c}\text { TOTAL } \\
2016\end{array}$ \\
\hline 1 & Bali & 4 days 3 nights & 25 & 240 & 6000 \\
\hline 2 & Bandung & 3 days 2 nights & 24 & 180 & 4320 \\
\hline 3 & Jakarta & 2 days 1 night & 20 & 144 & 2880 \\
\hline 4 & Yogyakarta & 3 days 2 nights & 19 & 171 & 3249 \\
\hline 5 & Medan & 4 days 3 nights & 15 & 60 & 900 \\
\hline 6 & Makassar & 4 days 3 nights & 15 & 120 & 1800 \\
\hline 7 & Padang & 3 days 2 nights & 13 & 84 & 1092 \\
\hline 8 & Lampung & 2 days 1 night & 10 & 72 & 720 \\
\hline 9 & Aceh & 3 days 2 nights & 6 & 60 & 360 \\
\hline 10 & Palembang & 3 days 2 nights & 5 & 24 & 120 \\
\hline
\end{tabular}

Source: Research Data Analysis

Table 5

Sales of inbound tour package by 25 sample of travel agencies

January 2017 to Desember 2017

\begin{tabular}{|c|c|c|c|c|c|}
\hline RANK & $\begin{array}{c}\text { PROVINCE/CI } \\
\text { TY }\end{array}$ & $\begin{array}{c}\text { A VERAGE } \\
\text { OF } \\
\text { PACKAGE'S } \\
\text { DURA TION }\end{array}$ & $\begin{array}{c}\text { QTY OF } \\
\text { TRA VEL } \\
\text { AGENCIE } \\
\text { S }\end{array}$ & $\begin{array}{c}\text { A VERAG } \\
\text { E SALES }\end{array}$ & $\begin{array}{l}\text { TOTA } \\
\text { L 2016 }\end{array}$ \\
\hline 1 & Bali & 4 days 3 nights & 25 & 184 & 4600 \\
\hline 2 & Bandung & 3 days 2 nights & 24 & 160 & 3840 \\
\hline 3 & Jakarta & 2 days 1 night & 20 & 180 & 3600 \\
\hline 4 & Yogyakarta & 3 days 2 nights & 19 & 112 & 2128 \\
\hline 5 & Medan & 4 days 3 nights & 15 & 96 & 1440 \\
\hline 6 & Makassar & 4 days 3 nights & 15 & 144 & 2160 \\
\hline 7 & Padang & 3 days 2 nights & 13 & 84 & 1092 \\
\hline
\end{tabular}

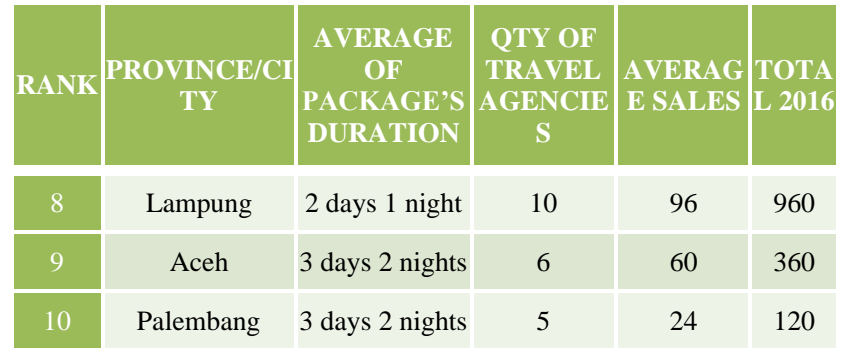

Source: Research Data Analysis

Table 6. Sales of inbound tour package by 25 sample of travel agencies

January 2018 to July 2018

\begin{tabular}{|c|c|c|c|c|c|}
\hline RANK & $\begin{array}{c}\text { PROVINCE } \\
\text { /CITY }\end{array}$ & $\begin{array}{l}\text { A VERAGE OF } \\
\text { PACKAGE'S } \\
\text { DURATION }\end{array}$ & $\begin{array}{c}\text { QTY OF } \\
\text { TRAVEL } \\
\text { AGENCIES }\end{array}$ & $\begin{array}{l}\text { AVERAGE } \\
\text { SALES }\end{array}$ & $\begin{array}{l}\text { TOTAL } \\
2016\end{array}$ \\
\hline 1 & Bali & 4 days 3 nights & 25 & 32 & 800 \\
\hline 2 & Bandung & 3 days 2 nights & 24 & 120 & 2880 \\
\hline 3 & Jakarta & 2 days 1 night & 20 & 96 & 1920 \\
\hline 4 & $\begin{array}{c}\text { Yogyakart } \\
\text { a }\end{array}$ & 3 days 2 nights & 19 & 72 & 136 \\
\hline 5 & Medan & 4 days 3 nights & 15 & 88 & 1320 \\
\hline 6 & Makassar & 4 days 3 nights & 15 & 80 & 1200 \\
\hline 7 & Padang & 3 days 2 nights & 13 & 56 & 728 \\
\hline 8 & Lampung & 2 days 1 night & 10 & 16 & 160 \\
\hline 9 & Aceh & 3 days 2 nights & 6 & 4 & 24 \\
\hline 10 & Palembang & 3 days 2 nights & 5 & 48 & 240 \\
\hline
\end{tabular}

Source: Research Data Analysis

From table 4 to table 6 , it can be seen that the process of increasing sales of inbound tour packages by 25 travel agency companies in the Bandung Raya area with the destination of 10 major provinces in Indonesia experiencing a very significant increased of sales in 2018, which still running for 7 (seven) months (January to July). The increasing in year 2018 especially in Jakarta, Bandung and Palembang is happened because of in 2018 especially in August and September, the Asian Games were held in Indonesia, in two cities: Jakarta and Palembang. So that many tourists who bought some packages from the 25 tour and travel companies, then add some length of stay and add a new destination, Palembang. This is an anomaly since usually they only bought one city as destination, without a visit to Palembang. 
Table 7. Total sales of inbound tour package by 25 sample of travel agencies

January 2016 to July 2018

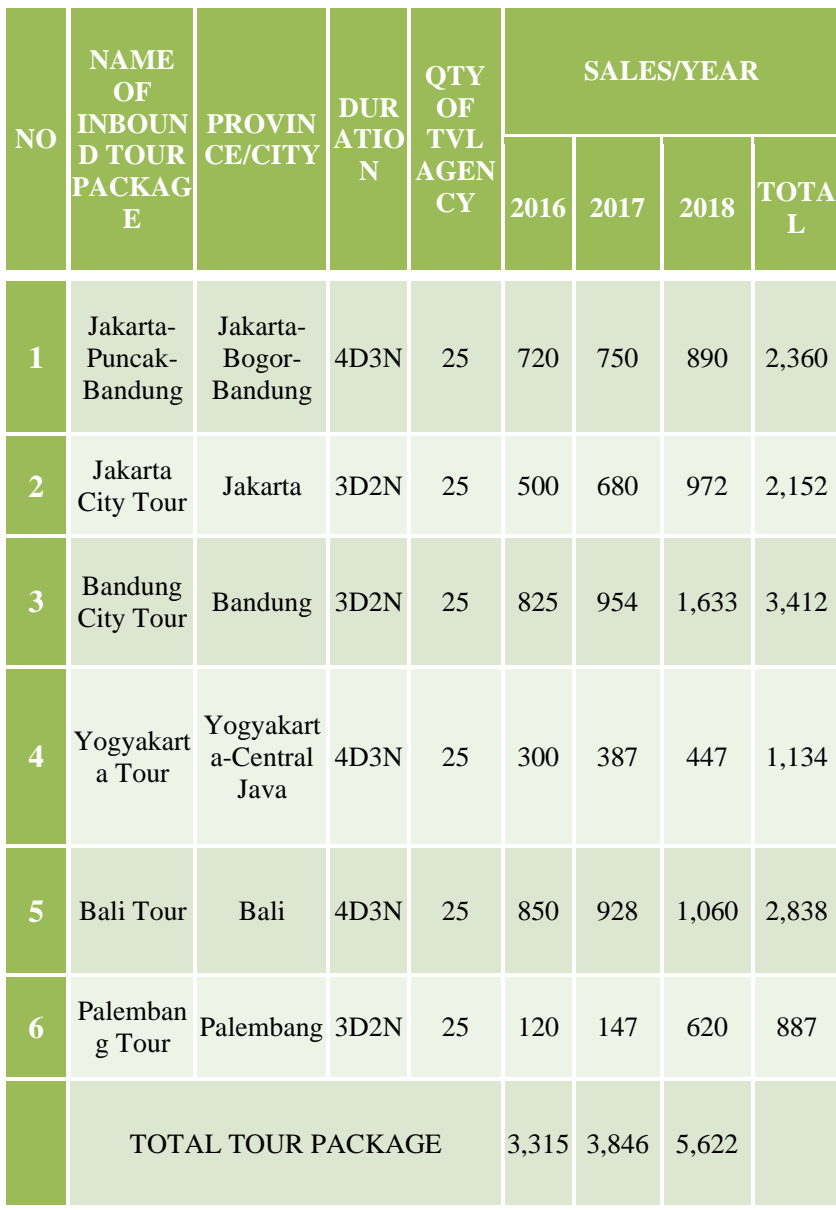

Source: Research Data Analysis

\section{B. The formula of packaging The Asian Games as a sport} tourism attraction in inbound tour.

According to the understanding of tour agenda or itinerary: a document that consisted of all the activities of the tour in detail since the departure until they coming back home. The finding on this research from the interview with the leader of the 25 travel companies got a result that majority of the respondents said that in arranging the itinerary there are some steps/activities which related with the principles of management, such as: Planning, Organizing, Actuating and Controlling, on the itinerary.

Based on the data analysis, referring to interview results, then it can be described that the flows for tour package arrangement as below:
Figure 2. Steps of planning a tour agenda / itinerary

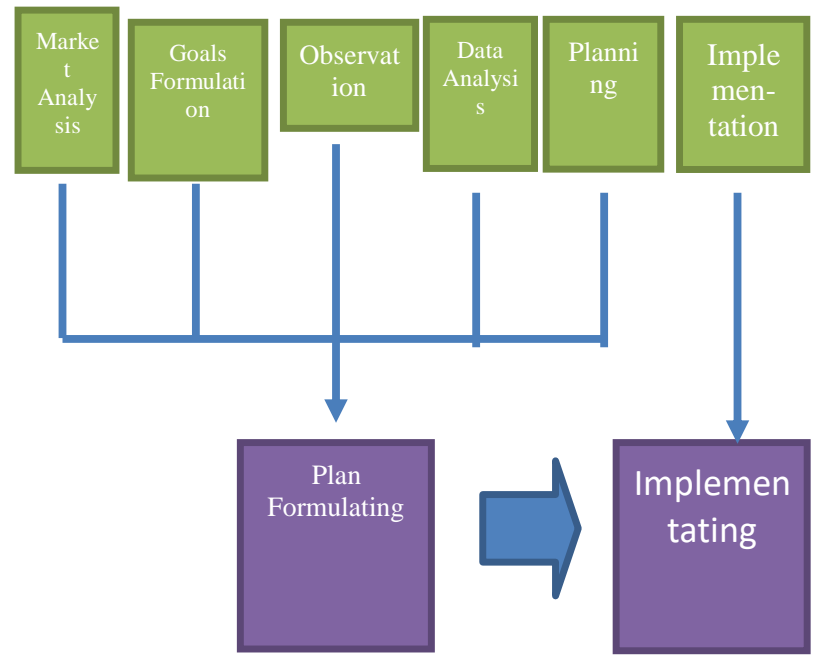

Source: Research Data Analysis

By the flow of arranging the tour package agenda or itinerary above, then the tour planner can effort to escalate through some innovation or variety of the destinations options. These options can be inserted to a tour package that match with the situation, condition and the desire of the tourists, according to the event of Asian Games 2018, on August 18 to September 2, 2018. There are 20 of those 25 travel companies that add the duration on tour package, especially the one with destination to Jakarta and Palembang, for 2 days 1 night. Based on interview data, there are some significant increase in tour package selling that add some agenda of Asian Games in the tour package.

Whilst from the result of some interviews with the 25 travel companies, most of them explain about some strategies or formulations in arranging the itinerary for a tour package by adding an international sport event such like Asian Games. Here are some basic things that needs to be known in advance:

1. The accessibilities for the transportation from their countries to the cities where the Asian Games held.

2. The accessibilities for local transportations to the venue of the games and the local transportation mode allowed by the committee.

3. All the shcedule and venue of the sport games

4. The favorit sport games from their countries

5. Tips to get the games tickets

6. The caring capacities for each games that would be added in the tour package

7. Dining facilities should not too far from the venue

After the itinerary arranged, the 20 travel companies that added sport event in their itinerary then publish the itinerary arrangement in three ways: Narration, Tables and Graphics. 


\section{CONCLUSION}

Based on the result and finding of this research, the authors conclude as below:

1. There are 25 of 187 travel companies, (13\%) concerned about inbound tour, by having 10 cities as their destinations. Sorted from these 25 companies, 5 travel companies add Palembang as destination in their tour package. As innovation in arranging the itinerary of tour package in Palembang, they added the event of Asian Games to extend the duration of inbound tour.

2. In adding the international sport event in their itinerary, the travel companies do some steps in formulating the itinerary by using the principles of management, such as Planning, Organizing, Actuating, and Controlling (POAC). This formula applied with the consideration of the 7 (seven) standard indicators on Asian Games event.

\section{REFERENCES}

(1) Desky, Pengantar Bisnis Biro Perjalanan Wisata, Adicita Yogyakarta, 2001, pp 23

(2) Getz, D, Event Management and Event Tourism, New York, Cognizant Communcation Corporation.1997, pp 25

(3) KBBI (Indonesian Dictionary) Event Definition

(4) Kesrul, Penyelenggaraan operasi perjalanan wisata, PT. Gramedia Widisarana, Jakarta, 2003, pp, 29-41

(5) Noor, A, Manajemen Event: Bandung: Alfabeta, 2013, pp, 10-13

(6) Nuriata, Paket Wisata (Penyusunan Produk dan penhitungan harga) Alfabeta, Bandung, April 2014, pp 27.

(7) Shone, A and Parry, B., Succesful events Management, A practical Handbook, London, Continum, 2002, pp,

(8) Suyitno, Perencanaan wisata, Kanisius Yogyakarta, 2001, pp, 67-69

(9) UU RI No. 10 tahun 2009 tentang kepariwisataan

(10) Yoeti, Pengantar ilmu pariwisata, Pradnya Paramita, Jakarta, 2010, pp, 75

(11) www.asitajabar.org 